\title{
PINEAPPLE YIELD AND FRUIT QUALITY EFFECTED BY NPK FERTILIZATION IN A TROPICAL SOIL ${ }^{1}$
}

\author{
ADEMAR SPIRONELLO ${ }^{2,3}$, JOSÉ ANTONIO QUAGGIO ${ }^{2,3}$, LUIZ ANTONIO JUNQUEIRA TEIXEIRA ${ }^{2}$, PEDRO \\ ROBERTO FURLANI ${ }^{2,3}$, JOSÉ MARIA MONTEIRO SIGRIST ${ }^{3,4}$
}

\begin{abstract}
There is a lack of information about fertilization of pineapple grown in the State of São Paulo, Brazil. So a field experiment with pineapple 'Smooth Cayenne' was carried out to study the effects of NPK rates on yield and fruit quality. The trial was located on an Alfisol in the central part of the State of São Paulo (Agudos county). The experimental design was an incomplete NPK factorial, with 32 treatments set up in two blocks. The P was applied only at planting, at the rates of $0 ; 80 ; 160$ and $320 \mathrm{~kg} / \mathrm{ha}$ of $\mathrm{P}_{2} \mathrm{O}_{5}$, as superphosphate. The $\mathrm{N}$ and $\mathrm{K}_{2} \mathrm{O}$ rates were $0 ; 175 ; 350$, and $700 \mathrm{~kg} / \mathrm{ha}$, applied as urea and potassium chloride, respectively, divided in four applications during the growth period. Response functions were adjusted to yield or to fruit characteristics in order to estimate the nutrient rates required to reach maximum values. The results showed quadratic effects of $\mathrm{N}$ and $\mathrm{K}$ on yield and a maximum of $72 \mathrm{t} / \mathrm{ha}$ of fresh fruit was attained with rates of 498 and $394 \mathrm{~kg} / \mathrm{ha}$, respectively of $\mathrm{N}$ and $\mathrm{K}_{2} \mathrm{O}$. In order to reach the maximum fruit size, and to improve the percentage of first class fruit (mass greater than $2.6 \mathrm{~kg}$ ), were necessary rates of $\mathrm{N}$ and $\mathrm{K}$ respectively 11 and $43 \%$ higher than those for maximum yield. No effect of $\mathrm{P}$ rates was observed on pineapple plant growth, despite the low availability of this nutrient in the soil. The effect of $\mathrm{N}$ rates was negative on total soluble solids and total acidity while the opposite occurred with $\mathrm{K}$, which increased also the content of vitamin C. High yield and fruit size were closely related to $\mathrm{N}$ and $\mathrm{K}$ concentrations in the leaves.

Index terms: Ananas comosus (L.) Merrill, mineral nutrition, growth, soil fertility, and tropics.
\end{abstract}

\section{PRODUÇÃO E QUALIDADE DE FRUTOS DE ABACAXIZEIRO EM RESPOSTA À ADUBAÇÃo COM NPK}

RESUMO - Há falta de informações sobre adubação de abacaxizeiro em São Paulo. Assim, um experimento de campo com abacaxizeiro 'Smooth Cayenne' foi desenvolvido com o objetivo de estudar os efeitos de doses de NPK na produção e qualidade de frutos em Agudos, região central do Estado, num Argissolo Vermelho-Amarelo. Empregou-se um fatorial incompleto, com 32 tratamentos distribuídos em dois blocos. O P foi aplicado somente no plantio nas doses de $0 ; 80 ; 160$ e $320 \mathrm{~kg} / \mathrm{ha} \mathrm{de} \mathrm{P}_{2} 0_{5}$, como superfosfato. As doses de $\mathrm{Ne} \mathrm{K}_{2} \mathrm{O}$ foram 0;175; 350 e 700 kg/ha, aplicadas como uréia e cloreto de potássio, respectivamente, parceladas em quatro aplicações, durante o período de crescimento da cultura. Ajustaram-se funções de resposta para a produção e características de qualidade dos frutos com o objetivo de estimar as doses de N, P e K para atingir valores máximos. Observou-se resposta quadrática na produção, com um máximo de $72 \mathrm{t} / \mathrm{ha}$ de frutos frescos estimado para as doses de 498 e $394 \mathrm{~kg} / \mathrm{ha}$ de $\mathrm{N}$ e $\mathrm{K}_{2} \mathrm{O}$, respectivamente. Para a maximização do tamanho do fruto e da porcentagem de frutos de primeira classe (massa maior que $2,6 \mathrm{~kg}$ ), as doses de $\mathrm{N}$ e $\mathrm{K}$ foram, respectivamente, 11 e $43 \%$ maiores daquelas necessárias para atingir a produção máxima. Não foi observado efeito das doses de $\mathrm{P}$ no crescimento ou produção, mesmo com a baixa disponibilidade do nutriente no solo da área experimental. O aumento nas doses de $\mathrm{N}$ diminuiu o teor de sólidos solúveis totais e acidez total titulável, enquanto o oposto ocorreu com as doses de $\mathrm{K}$, que aumentaram também os teores de vitamina C. Produção e tamanho de fruto apresentaram relação positiva com os teores de $\mathrm{N}$ e de $\mathrm{K}$ nas folhas.

Termos para indexação: abacaxi, Ananas comosus (L.) Merrill, nutrição mineral, crescimento, fertilidade do solo, região tropical.

\section{INTRODUCTION}

Despite the importance of the pineapple to fruit crop production in the State of São Paulo, there is a lack of information on the responses to NPK fertilizers and their influence on fruit size and quality in order to assure reliable recommendations to the growers.

Major responses have been observed to rates of nitrogen and potassium mainly for the 'Pérola' variety (Reinhardt \& Neiva, 1986; Paula et al., 1991; Veloso et al., 2001). Small or no response to phosphorus fertilizer has been found, even in soil with low P availability (Reinhardt \& Neiva, 1986; Buzetti et al., 1986; Botrel et al., 1991). An exception was observed by Giacomelli et al. (1971), who reported a linear response of fruit size to $\mathrm{P}$ rates from 0 to $2.2 \mathrm{~g}$ of $\mathrm{P}$ per plant with the 'Smooth Cayenne' variety in a sandy soil with very low $P$.

The influence of $\mathrm{N}$ and $\mathrm{K}$ fertilization on pineapple fruit size and quality is pronounced (Teisson et al., 1979; Souza, 1999). Nitrogen fertilizer usually increases fruit size (Paula et al., 1991), juice content (Reinhardt \& Neiva, 1986; Veloso et al., 2001) while decreases total soluble solids (TSS) and vitamin C (Teisson et al., 1979; Paula et al., 1991). Teixeira et al. (2002) observed that late application of $\mathrm{N}$ had a positive effect on fruit yield but decreased TSS. Potassium has a positive effect on fruit size, TSS and total acidity (Reinhardt \& Neiva, 1986; Paula et al., 1991). The effect of $\mathrm{P}$ rates on fruit quality is normally lower than that observed for N and K (Quaggio, 1995; Souza, 1999).

This work was planned to establish the effects of NPK rates on the quantitative responses of pineapple as well as to determine the rates and combinations of these nutrients to obtain the maximum yield and fruit quality.

\section{MATERIAL AND METHODS}

The experiment was carried out in a sandy and low fertility Alfisol located in Agudos, inside an important producing area in the central part of the State of São Paulo (SP), Brazil. Some soil chemical characteristics of the plot before the experiment were: organic matter $=17 \mathrm{~g} / \mathrm{kg}$, P-resin $=7.5 \mathrm{mg} / \mathrm{dm}^{3}, \mathrm{pH}$ in $0,01 \mathrm{M} \mathrm{CaCl}_{2}$ solution $=4.1$, exchangeable $\mathrm{K}, \mathrm{Ca}$, and $\mathrm{Mg}=1.5,7$, and 3, respectively, $(\mathrm{H}+\mathrm{Al})=31$, $\mathrm{CEC}=42$, in $\mathrm{mmol} / \mathrm{dm}^{3}$, and soil base saturation $=27 \%$ according to the methods proposed by Raij et al. (1983). In order to reduce the soil acidity $2 \mathrm{t} /$ ha of dolomitic limestone were applied. The climate was classified as Cwa-Köppen with dry winter.

The experimental design was an incomplete NPK factorial of the type $(1 / 2) 4^{3}$, with 32 treatments set up in two blocks, as proposed by Colwell (1978), with treatments adjusted by Andrade and Noleto (1986) to allow calculations of all first order interactions. All treatments were set up in duplicate in the field and statistical analyses were performed to average values. The $\mathrm{P}$ was applied, as ordinary superphosphate, only at planting, at the rates of $0,80,160$, and $320 \mathrm{~kg} / \mathrm{ha}$ of $\mathrm{P}_{2} 0_{5}$. Gypsum was used to equilibrate the rates of $\mathrm{S}-\mathrm{S}_{4}$ carried by the $\mathrm{P}$ fertilizer. The $\mathrm{N}$ and $\mathrm{K}_{2} \mathrm{O}$ rates were $0,175,350$, and $700 \mathrm{~kg} / \mathrm{ha}$, applied as urea and potassium

\footnotetext{
${ }^{1}$ (Trabalho 106/2003). Recebido: 04/09/2003. Aceito para publicação: 17/02/2004.

${ }^{2}$ Researchers, Instituto Agronômico - IAC. PO Box 28, 13001-970, Campinas-SP, Brazil. e mail: quaggio@iac.sp.gov.br

${ }^{3}$ With research grant from National Scientific and Technologic Research Council (CNPq), Brazil

${ }^{4}$ Researcher, Instituto de Tecnologia de Alimentos - ITAL, Campinas-SP, Brazil.
} 
TABLE 1 - Effects of N, P and K application on 'Smooth Cayenne' pineapple yield, fruit weight and size and fruit pulp contents of total soluble solids (TSS), total titrable acidity (TTA) and vitamin C. Agudos (SP), 1997.

\begin{tabular}{|c|c|c|c|c|c|c|c|c|}
\hline \multirow{2}{*}{$\begin{array}{l}\text { Rates of } \\
\text { Nutrients }\end{array}$} & \multicolumn{2}{|c|}{ Fruit } & \multicolumn{3}{|c|}{ Fruit size } & \multicolumn{3}{|c|}{ Pulp analysis } \\
\hline & Yield & Weight $^{(1)}$ & Large $^{(2)}$ & Medium $^{(3)}$ & Small ${ }^{(4)}$ & $\mathbf{T S S}^{(5)}$ & TTA $^{(6)}$ & Vit. $C^{(7)}$ \\
\hline $\mathrm{Kg} / \mathrm{ha}$ & $\mathrm{t} / \mathrm{ha}$ & $\mathrm{kg}$ & \multicolumn{3}{|c|}{--------------- \% -------------- } & ${ }^{\circ}$ Brix & $\mathrm{g} / \mathrm{kg}$ & $\mathrm{mg} / \mathrm{kg}$ \\
\hline \multicolumn{9}{|l|}{ Nitrogen } \\
\hline 0 & 39.3 & 1.71 & 3 & 18 & 79 & 14.8 & 9.3 & 151 \\
\hline 175 & 60.0 & 2.29 & 29 & 51 & 21 & 14.3 & 8.0 & 148 \\
\hline 350 & 64.2 & 2.44 & 38 & 51 & 11 & 13.6 & 7.4 & 141 \\
\hline 700 & 64.7 & 2.50 & 50 & 45 & 5 & 13.5 & 7.6 & 141 \\
\hline Trends & $\mathrm{L}^{* *} \mathrm{Q}^{* *}$ & $\mathrm{~L}^{* *} \mathrm{Q}^{*}$ & $\mathrm{~L}^{* *} \mathrm{Q}^{*}$ & $\mathrm{~L}^{*} \mathrm{Q}^{*}$ & $\mathrm{~L}^{* *} \mathrm{Q}^{* *}$ & $\mathrm{~L}^{*} \mathrm{Q}^{*}$ & $\mathrm{~L}^{* *} \mathrm{Q}^{*}$ & NS \\
\hline \multicolumn{9}{|l|}{$\mathbf{P}_{2} \mathbf{O}_{5}$} \\
\hline 0 & 55.5 & 2.21 & 32 & 41 & 27 & 14.0 & 8.3 & 143 \\
\hline 80 & 59.1 & 2.31 & 33 & 44 & 23 & 14.0 & 7.8 & 163 \\
\hline 160 & 57.8 & 2.21 & 26 & 39 & 35 & 14.1 & 8.1 & 145 \\
\hline 320 & 55.8 & 2.20 & 29 & 41 & 30 & 14.2 & 8.0 & 153 \\
\hline Trends & NS & NS & NS & NS & NS & NS & NS & NS \\
\hline \multicolumn{9}{|l|}{$\mathbf{K}_{2} \mathbf{O}$} \\
\hline 0 & 53.8 & 2.05 & 15 & 46 & 39 & 13.7 & 6.1 & 110 \\
\hline 175 & 57.8 & 2.25 & 28 & 42 & 30 & 14.0 & 8.2 & 145 \\
\hline 350 & 60.4 & 2.33 & 37 & 43 & 20 & 14.4 & 8.9 & 151 \\
\hline 700 & 56.2 & 2.31 & 40 & 33 & 27 & 14.1 & 8.8 & 166 \\
\hline Trends & $\mathrm{L}^{* *} \mathrm{Q}^{* *}$ & $\mathrm{~L}^{* *} \mathrm{Q}^{* *}$ & $\mathrm{~L}^{*} \mathrm{Q}^{*}$ & NS & $\mathrm{L}^{*} \mathrm{Q}^{*}$ & $\mathrm{~L}^{*} \mathrm{Q}^{*}$ & $L^{* *} Q^{* *}$ & $\mathrm{~L}^{* *} \mathrm{Q}^{*}$ \\
\hline CV (\%) & 9.5 & 6.5 & 56.3 & 419 & 46.9 & 3.9 & 7.8 & 7.9 \\
\hline
\end{tabular}

L: linear; Q: quadratic; NS: not significant $(p>0.05)$; ${ }^{*}$ : significant $(0.001<p<0.05)$; $^{* *}$ : significant $(p<0.001){ }^{(1)}$ Average weight of fruits ${ }^{(2)}$ Large: $>2.6$ kg; ${ }^{(3)}$ Medium: 2.0 to $2.6 \mathrm{~kg} ;{ }^{\left({ }^{4}\right)}$ Small: $<2.0 \mathrm{~kg} ;{ }^{(5)}$ Total soluble solids; ${ }^{\left({ }^{6}\right)}$ Total titrable acidity $=\mathrm{g}$ of citric acid $/ \mathrm{kg}$ of pulp; ${ }^{(7)} \mathrm{Vitamin} \mathrm{C}=\mathrm{mg}$ of ascorbic acid $/ \mathrm{kg}$ of pulp.

chloride, respectively. These rates were split into four applications during the growth period, as follows: $11.4 \%, 17.1 \%, 28.6 \%$, and $42.9 \%$ applied, respectively, at one, six, eight and ten months after planting.

The plots had six double rows $(0.50 \mathrm{~m}$ by $1.15 \mathrm{~m})$ with $3.6 \mathrm{~m}$ long. The spacing between plants was $0.4 \mathrm{~m}$, summing up about 30,300 plants per ha. Only the four central double rows, with an area of $18.5 \mathrm{~m}^{2}$ were used for evaluations ( 56 plants).

Selected slips of the 'Smooth Cayenne' variety, previously treated with fungicides and pesticides were planted in May, 1995. The floral induction occurred spontaneously in about $80-90 \%$ of the plants. The remaining were artificially induced to flower by spraying $3 \mathrm{~L} / \mathrm{ha}$ of a solution composed of Ethephon (21.7\%) and urea (2\%), in August, 1996.

Just before flowering (September, 1996), leaf samples were taken to determine the total concentrations of nutrients. The sample comprised the $20 \mathrm{~cm}$ long central part of 20 "D" leaves collected from each plot (Lacoeuilhe, 1984). The chemical analyses were carried out according to the methods described by Bataglia et al. (1983).

Fruits were harvested 21 months after planting (February, 1997). They were classified, according to the individual weight, in large, medium and small and expressed as the percent in relation to the total yield. A combined sample of four fruits per plot was used to evaluate the pulp quality (total titrable acidity - TTA, total soluble solids - TSS and vitamin C) according to the methods described by Carvalho (1990).

Response functions of the type $\mathbf{Y}=\mathbf{b}_{0}+\mathbf{b}_{1} \mathbf{N}+\mathbf{b}_{2} \mathbf{N}^{2}+\mathbf{b}_{3} \mathbf{P}+\mathbf{b}_{4} \mathbf{P}^{2}$ $+\mathbf{b}_{5} \mathbf{K}+\mathbf{b}_{6} \mathbf{K}^{2}+\mathbf{b}_{7} \mathbf{N P}+\mathbf{b}_{8} \mathbf{N K}+\mathbf{b}_{9} \mathbf{P K}$ were adjusted to all measured variables, where $\mathrm{Y}$ is the dependent variable, $\mathrm{b}_{0} . . . \mathrm{b}_{9}$ are the regression coefficients, and $\mathrm{N}, \mathrm{P}$, and $\mathrm{K}$ are the rates of $\mathrm{N}, \mathrm{P}_{2} \mathrm{O}_{5}$ and $\mathrm{K}_{2} \mathrm{O}$, respectively. Significance of $\mathrm{b}_{0} \ldots \mathrm{b}_{9}$ coefficients was tested and new response functions were adjusted including only significant effects $(p<0,10)$. Simultaneous rates and ideal combinations of nutrients for maximum values of a desirable variable were calculated.

\section{RESULTS AND DISCUSSION}

The effects of $\mathrm{N}, \mathrm{P}$ and $\mathrm{K}$ application on yield and fruit characteristics are shown in Table 1. The analysis of variance showed no response to phosphorus, despite its low availability in the soil. These results are in agreement with those previously reported by Reinhardt \& Neiva (1986), Botrel et al. (1991), and Paula et al. (1991) from experiments carried out in other Brazilian soils. This confirms that pineapple response to phosphorus fertilizer is small or null, even in low soil-P conditions.

The nitrogen supply increased yield, fruit size and the percentage of large fruits from 3 to $50 \%$, in agreement to previous field trials results obtained by Montenegro et al (1967), Reinhardt \& Neiva (1986), Obiefuna et al. (1987), and Paula et al. (1991). The increase in nitrogen supply caused a reduction in the TSS and TTA (Table 1) of the fruit pulp. These results were similar to those reported by Montenegro et al. (1967), Teisson et al. (1979), Paula et al. (1991), and Teixeira et al. (2002).

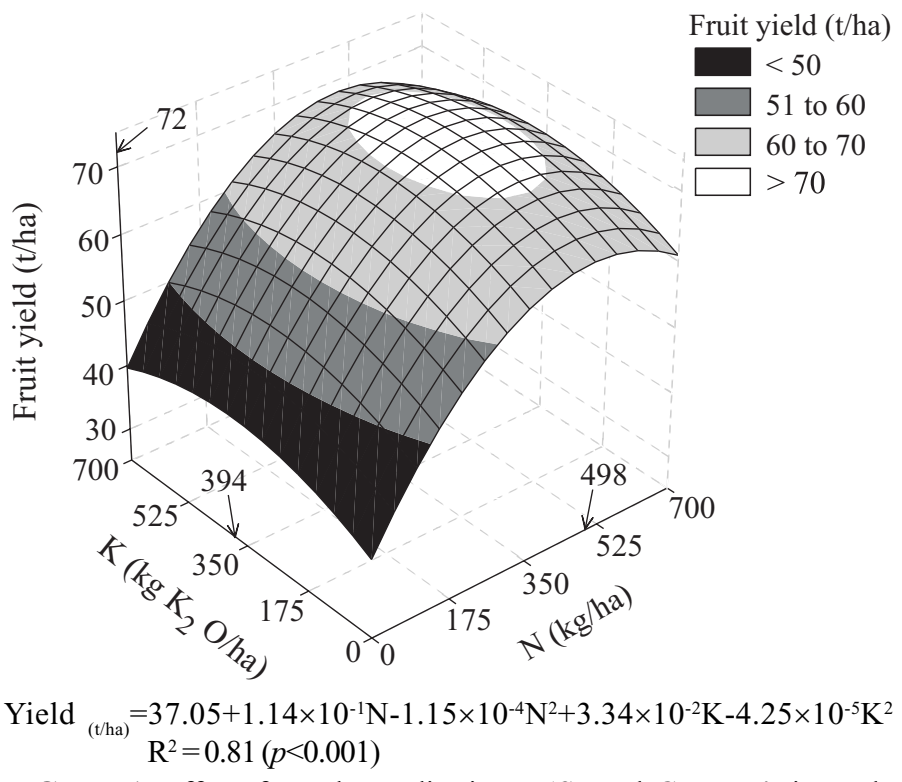

FIGURE 1 - Effect of N and K application on 'Smooth Cayenne' pineapple fruit yield. The marked values predict maximum fruit yield. Agudos (SP), 1997. 
TABLE 2 - Effects of N, P and K application on nutrients concentrations in 'Smooth Cayenne' pineapple “D” leaves. Agudos (SP), 1997.

\begin{tabular}{|c|c|c|c|c|c|c|c|c|c|c|}
\hline $\begin{array}{l}\text { Rates of } \\
\text { nutrients }\end{array}$ & $\mathbf{N}$ & $\mathbf{P}$ & $\mathbf{K}$ & $\mathrm{Ca}$ & Mg & B & $\mathbf{C u}$ & $\mathbf{F e}$ & Mn & Zn \\
\hline $\mathrm{kg} / \mathrm{ha}$ & \multicolumn{5}{|c|}{ 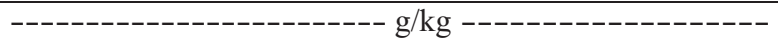 } & \multicolumn{5}{|c|}{ 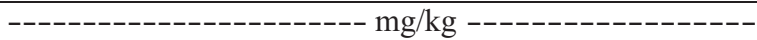 } \\
\hline \multicolumn{11}{|l|}{ Nitrogen } \\
\hline 0 & 8.2 & 1.1 & 22.7 & 3.0 & 2.8 & 8.6 & 4.3 & 83.9 & 208 & 6.2 \\
\hline 175 & 10.4 & 0.9 & 17.8 & 4.0 & 3.0 & 8.3 & 3.8 & 70.6 & 314 & 6.7 \\
\hline 350 & 13.2 & 0.9 & 18.3 & 4.4 & 3.2 & 7.4 & 3.5 & 76.3 & 428 & 7.2 \\
\hline 700 & 14.9 & 0.9 & 15.8 & 4.5 & 3.2 & 8.5 & 3.2 & 70.5 & 454 & 7.7 \\
\hline Trends & $\mathrm{L}^{* *} \mathrm{Q}^{*}$ & $\mathrm{~L}^{*}$ & $\mathrm{~L}^{* *} \mathrm{Q}^{*}$ & $\mathrm{~L}^{* *} \mathrm{Q}^{* *}$ & NS & NS & NS & NS & $\mathrm{L}^{* *} \mathrm{Q}^{*}$ & NS \\
\hline \multicolumn{11}{|l|}{$\mathbf{P}_{2} \mathbf{O}_{5}$} \\
\hline 0 & 11.9 & 0.9 & 18.0 & 3.9 & 3.1 & 8.0 & 3.9 & 73.8 & 345 & 6.9 \\
\hline 80 & 11.8 & 1.0 & 18.9 & 4.2 & 3.1 & 7.5 & 3.8 & 81.6 & 354 & 7.1 \\
\hline 160 & 11.8 & 1.0 & 19.0 & 3.9 & 3.0 & 8.0 & 3.7 & 77.5 & 356 & 7.1 \\
\hline 320 & 11.1 & 1.0 & 18.7 & 3.9 & 3.2 & 9.2 & 3.3 & 68.4 & 349 & 6.8 \\
\hline Trends & NS & $\mathrm{L}^{*}$ & NS & NS & NS & NS & NS & NS & NS & NS \\
\hline \multicolumn{11}{|l|}{$\mathrm{K}_{2} \mathrm{O}$} \\
\hline 0 & 13.6 & 1.0 & 9.6 & 5.0 & 4.2 & 8.9 & 4.1 & 81.4 & 324 & 7.3 \\
\hline 175 & 12.2 & 1.0 & 16.7 & 4.0 & 3.1 & 8.2 & 3.8 & 75.9 & 371 & 7.1 \\
\hline 350 & 11.0 & 0.9 & 21.2 & 3.7 & 2.8 & 7.3 & 3.4 & 78.1 & 346 & 6.8 \\
\hline 700 & 9.9 & 0.9 & 27.2 & 3.1 & 2.3 & 8.3 & 3.6 & 65.9 & 363 & 6.6 \\
\hline Trends & $\mathrm{L}^{*}$ & NS & $\mathrm{L}^{* *} \mathrm{Q}^{* *}$ & $\mathrm{~L}^{* *} \mathrm{Q}^{* *}$ & $\mathrm{~L}^{* *} \mathrm{Q}^{* *}$ & NS & $\mathrm{L}^{*}$ & NS & NS & NS \\
\hline CV $(\%)$ & 8.7 & 12.1 & 9.6 & 9.6 & 10.0 & 26.5 & 11.8 & 19.9 & 18.9 & 9.6 \\
\hline
\end{tabular}

L: linear; Q: quadratic; NS: not significant $(p>0.05)$; *: significant $(0.001<p<0.05) ; * *$ : significant $(p<0,001)$

The rates of potassium had a positive influence on pineapple yield and fruit size (Table 1), as also shown by other authors. However, the effects were less pronounced than those obtained for nitrogen. Potassium rates had opposite effects to those of $\mathrm{N}$ on TSS, TTA and vitamin $\mathrm{C}$. The effect of $\mathrm{K}$ on increasing the values of these fruits characteristics followed the same pattern reported by Montenegro et al. (1967), Reinhardt \& Neiva (1986), and Paula et al. (1991).

The maximum yield of $72 \mathrm{t} / \mathrm{h}$ a of fresh fruit was attained with the rates of 498 and $394 \mathrm{~kg} / \mathrm{ha}$, of $\mathrm{N}$ and $\mathrm{K}_{2} \mathrm{O}$, respectively (Figure 1). To reach the maximum fruit size or to increase the percentage of large fruits, the rates of $\mathrm{N}$ and $\mathrm{K}$ should be higher than those to achieve maximum yield (Figure 2). These optimum rates confirmed the guidelines for $\mathrm{N}$ and $\mathrm{K}$ fertilizer recommendations, proposed by Spironello \& Furlani (1996), for pineapple crop in the State of São Paulo. On the other hand, the absence of a response to $\mathrm{P}$ fertilizer, in the low-P soil used in this experiment, showed that the $\mathrm{P}$ rates recommended by those authors may be overestimated.

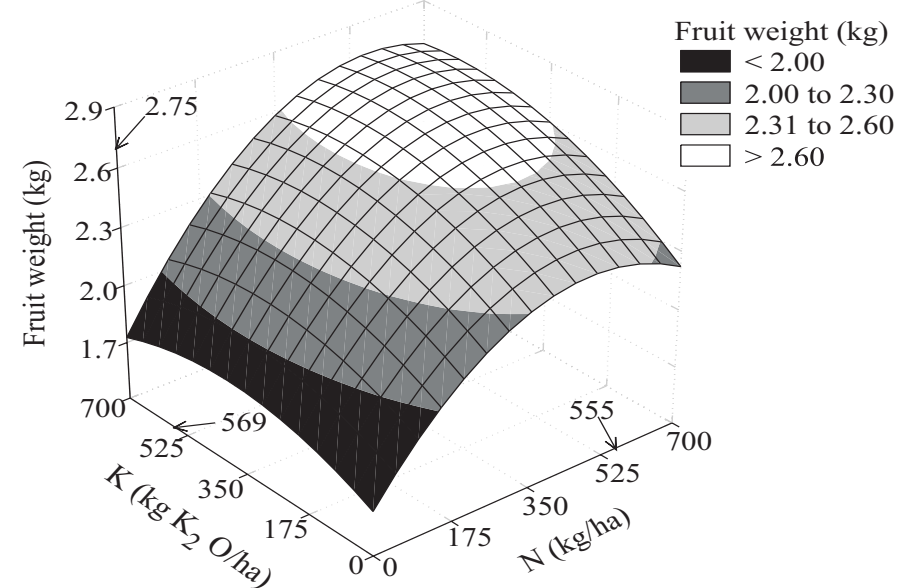

Weight $_{(\mathrm{kg})}=$

$1.63+3.01 \times 10^{-3} \mathrm{~N}-3.09 \times 10^{-6} \mathrm{~N}^{2}+1.01 \times 10^{-3} \mathrm{~K}-1.25 \times 10^{-6} \mathrm{~K}^{2}+7.45 \times 10^{-7} \mathrm{~N} \times \mathrm{K}$ $\mathrm{R}^{2}=0.87(p<0.001)$

FIGURE 2 - Effect of $\mathrm{N}$ and $\mathrm{K}$ application on average fuit weight of 'Smooth Cayenne' pineapple. The marked values predict maximum fruit weight. Agudos (SP), 1997.

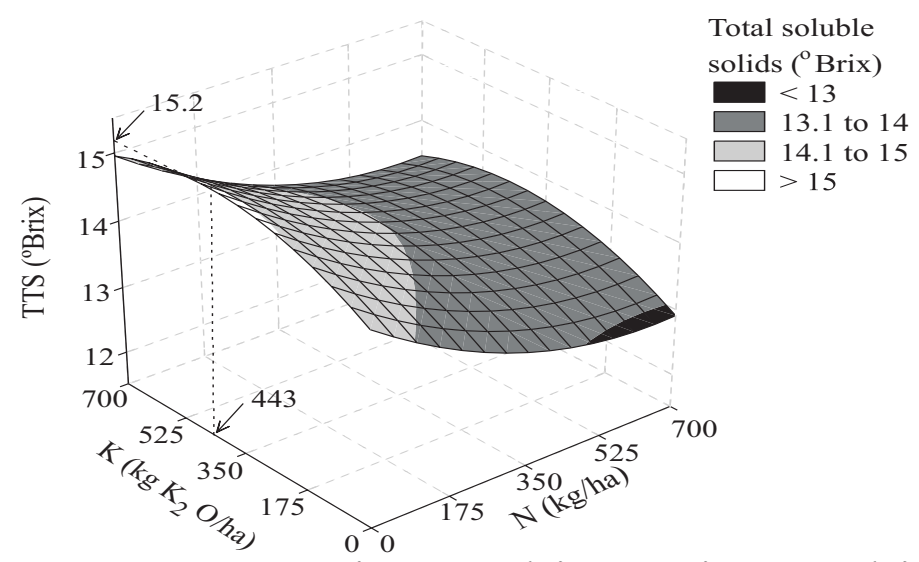

$\mathrm{TSS}_{\left({ }^{\circ} \text { Brix) }\right.}=14.42-4.73 \times 10^{-3} \mathrm{~N}+3.77 \times 10^{-6} \mathrm{~N}^{2}+3.60 \times 10^{-3} \mathrm{~K}-4.07 \times 10^{-6} \mathrm{~K}^{2}$ $\mathrm{R}^{2}=0.54(p<0.001)$

FIGURE 3 - Effect of N and K application on total soluble solids (TSS) contents of 'Smooth Cayenne' pineapple. The marked value predicts maximum TSS. Agudos (SP), 1997.

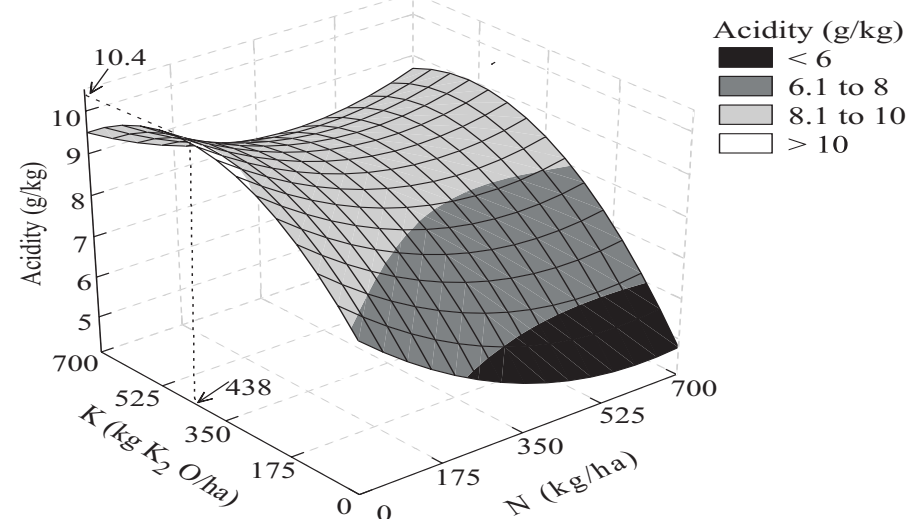

Acidity $_{(\mathrm{g} / \mathrm{kg})}=7.79-9.77 \times 10^{-3} \mathrm{~N}+7.83 \times 10^{-6} \mathrm{~N}^{2}+1.12 \times 10^{-2} \mathrm{~K}-1.38 \times 10^{-5} \mathrm{~K}^{2}+4.47 \times 10^{-6} \mathrm{~N} \times \mathrm{K}$ $\mathrm{R}^{2}=0.84(p<0.001)$

FIGURE 4 - Effect of $\mathrm{N}$ and $\mathrm{K}$ application on total titrable acidity of 'Smooth Cayenne' pineapple. The marked value predicts maximum fruit acidity. Agudos (SP), 1997. 


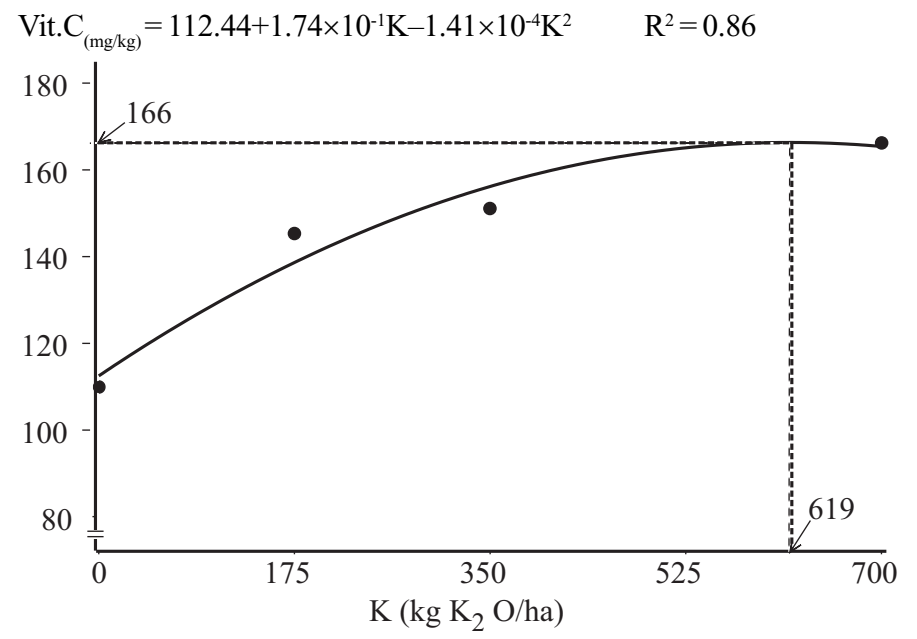

FIGURE 5 - Effect of K application on vitamin C contents of 'Smooth Cayenne' pineapple. The marked value predicts maximum Vit. C contents. Agudos (SP), 1997.

The effects of $\mathrm{N}$ and $\mathrm{K}$ were normally synergistic for yield and fruit size and complementary for pulp characteristics. The negative effects of increasing $\mathrm{N}$ rates on TSS and TTA were compensated by the effect of $\mathrm{K}$ supply on these fruit characteristics (Figures 3 and 4). Increasing rates of $\mathrm{K}$ also improved fruit quality enhancing vitamin $\mathrm{C}$ contents (Figure 5).

According to the results of this work, farmers must pay attention to $\mathrm{K}$ supply for pineapples, specially if they intend to produce high quality fruits. Cunha (1999) also mentioned this feature.

The effects of NPK on leaf chemical characteristics are presented in Table 2 . The treatments with nitrogen application caused a decrease in the concentrations of $\mathrm{K}$ and $\mathrm{P}$ and increased $\mathrm{Ca}$ and $\mathrm{Mg}$ in pineapple leaves. The observed trends might be related to the so called 'dilution effect' for the highest rate of $\mathrm{N}$ which promoted vigorous pineapple growth. The effects of NPK rates on the other micronutrients were less significant excepting on Mn leaf content.

The addition of $\mathrm{P}$ fertilizer had a little effect only on the concentration of leaf $\mathrm{P}$. On the other hand, $\mathrm{K}$ fertilization caused a marked reduction on the leaf concentrations of $\mathrm{N}, \mathrm{Ca}$, and $\mathrm{Mg}$, but did not affect those of P. These data are in agreement to the results published by Marchal et al. (1970), Hiroce et al. (1977), and Paula et al. (1991).

The regression of $\mathrm{N}$ and $\mathrm{K}$ in the leaves and fruit yield is shown on Figure 6 . The values to attain maximum fruit weight were practically the same (15.5 g/ kg for leaf-N and $37.2 \mathrm{~g} / \mathrm{kg}$ for leaf-K, figure not shown). The results of leaf-N are in agreement but those of leaf-K are higher than the sufficiency ranges presented by Lacoeuilhe (1984) for the ' $D$ ' pineapple leaf $(15-17 \mathrm{~g} / \mathrm{kg}$ for leaf-N and $22-30 \mathrm{~g} / \mathrm{kg}$ for leaf-K). Despite the absence of any response to $P$ fertilizer application, the concentration of this nutrient on the leaves - around $1.0 \mathrm{~g} / \mathrm{kg}$ - could be considered normal, because it was sufficient to assure high yield and fruit quality of pineapple.

\section{CONCLUSIONS}

1) Fruit yield and quality were influenced by rates of $\mathrm{N}$ and $\mathrm{K}$ fertilizers. Differently, application of $\mathrm{P}$ had no effect on fruit production.

2) Increasing rates of $N$ produced heavier fruits, increased yield but affected fruit quality adversely, reducing total soluble solids and total titrable acidity.

3) Fruit quality and yield were favoured by the rise of K supply.

4) Maximum fruit yield was attained with rates of 498 and 394 $\mathrm{kg} / \mathrm{ha}$ of $\mathrm{N}$ and $\mathrm{K}_{2} \mathrm{O}$, respectively.

\section{ACKNOWLEDGEMENT}

The authors are grateful to Milton and Armando Yoshiura,

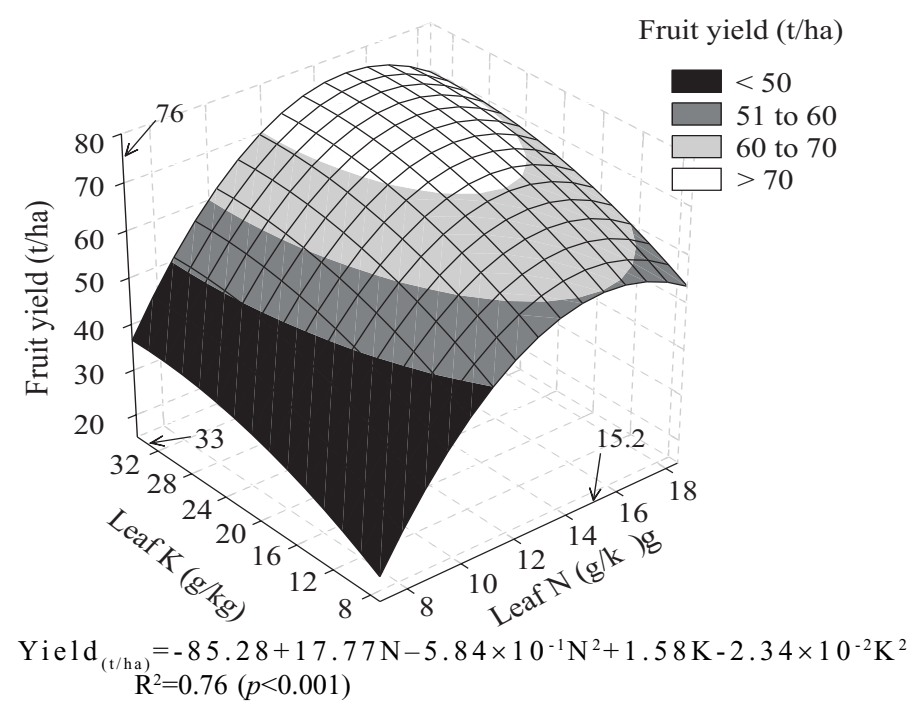

FIGURE 6 - Relationship between fruit yield and $\mathrm{N}$ and $\mathrm{K}$ concentrations in " $D$ " leaves of 'Smooth Cayenne' pineapple plants.The marked values predict maximum fruit yield. Agudos (SP), 1997.

owners of the plantation where the trial was developed, for their support for field activities.

\section{REFERENCES}

ANDRADE, D. F., NOLETO, A.Q. Exemplos de fatoriais fracionados (1/ 2) $4^{3}$ e $(1 / 4) 4^{4}$ para o ajuste de modelos polinomiais quadráticos. Pesquisa Agropecuária Brasileira, Brasília, v.21,n.6, p.677-680, 1986.

BATAGLIA, O.C., FURLANI, A.M.C., TEIXEIRA, J.P.F., FURLANI, P.R., GALLO, J.R. Métodos de análise química de plantas. Campinas: IAC, 1983. 48p. (Boletim Técnico, 78).

BOTREL, N., SIQUEIRA, D.L., PEDROSO NETO, J.C., PAULA, M.B. Efeito de diferentes fontes, níveis e modos de aplicação e fósforo na cultura do abacaxizeiro. Pesquisa Agropecuária Brasileira, Brasília, v.26, p.907-912, 1991.

BUZETTI, S., BIANCO, S., CORRÊAS, L.S., MARTINS, A.B.G., MATTIOLI, C.H. Doses de N.P.K e micronutrientes na cultura do abacaxizeiro. Pesquisa Agropecuária Brasileira, Brasília, v.21, p.1249-1252, 1986.

CARVALHO, C.R.L. Análises químicas de alimentos. Campinas: Instituto de Tecnologia de Alimentos, 1990. 121p. (Manual técnico)

COLWELL, J.D. Computations for studies of soil fertility and fertilizer requirements. Slough: Commonwealth Agricultural Bureaux, 1978. $297 \mathrm{p}$.

GIACOMELLI, E.J., LUCCHESI, A.A., HIROCE, R. Estudos sobre a adubação mineral do abacaxizeiro Cayenne em solo podzólico vermelho-amarelo, variação Laras, em Rio Claro, SP. In: CONGRESSO BRASILEIRODE FRUTICULTURA, 1., 1971, Campinas, SP. Anais... Campinas: SBF, 1971.p.43-55.

HIROCE, R., BATAGLIA, O.C., FURLANI, P.R., FURLANI, A.M.C., GIACOMELLI, E.J., GALLO, J.R. Composição química inorgânica do abacaxizeiro (Ananas comosus 'Cayenne') da região de Bebedouro, SP. Ciência e Cultura, São Paulo, v.29, p.323-326, 1977.

LACOEUILHE, J.J. Ananas. In: MARTIN-PRÉVEL, P., GAGNARD, J., GAUTIER, P. (Eds.) L'analyse végétale dans le contrôle de l'alimentation des plantes tempérées et tropicales. Paris: Tec\&Doc, 1984. p.715-751.

MARCHAL, J., MARTIN-PRÉVEL, P., LACOEUILHE, J.J., LOSSOIS, P. Recherché d'un équilibre $\mathrm{K} / \mathrm{N}$ dans la production de l'ananas frais au Cameroun. II. Analyses foliares. Fruits, Paris, v.25, p.87-95, 1970.

MONTENEGRO, H.W.W., TORRES, G., SILVA, G. Ensaio de adubação em Ananas comosus no Brasil. Fertilité, Paris, v.29, p.23-27, 1967. 
OBIEFUNA, J.C., MAJUMDER, P.K., UCHEAGWU, A.C. Fertilizer rates for increased pineapple production in the tropical ferralitic soils of South Western Nigeria. Fertilizer Research, Dordrecht, v.12, p.99105, 1987.

PAULA, M.B., CARVALHO, V.D., NOGUEIRA, F.D., SOUZA, L.F.S. Efeito da calagem, potássio e nitrogênio na produção e qualidade do fruto do abacaxizeiro. Pesquisa Agropecuária Brasileira, Brasília, v.26, p.1337-1343, 1991.

QUAGGIO, J.A. Adubação NPK e a qualidade de alguns frutos tropicais. In: PEREIRA, J.R., FARIA, C.M.B. Fertilizantes: insumo básico para a agricultura e combate à fome. REUNIÃO BRASILEIRA DE FERTILIDADE DO SOLO E NUTRIÇÃO DE PLANTAS, 21., 1994, Petrolina, PE. Anais... Petrolina: EMBRAPA/CPATSA/SBCS, 1995. p.166-194.

RAIJ, B. van, QUAGGIO, J.A., SILVA, N.M. Extraction of phosphorus, potassium, calcium, and magnesium from soils by ion exchange resin procedure. Communications in Soil Science and Plant Analysis, New York, v.17, p.547-566, 1986.

REINHARDT, D.H.R.C., NEIVA, L.P.A. Adubação NPK e fontes de potássio em abacaxi 'Pérola' na microregião baiana de Feira de Santana. In: CONGRESSO BRASILEIRO DE FRUTICULTURA, 8., 1986, Brasília, DF. Anais... Brasília: SBF, 1986. p.41-46.

SOUZA, L.F.S. Correção da acidez e adubação. In: CUNHA, G.A.P., CABRAL, J.R.S., SOUZA, L.F.S. O abacaxizeiro: cultivo, agroindústria e economia. Brasília: EMBRAPA, 1999. p.169-202.

SPIRONELLO, A., FURLANI, P.R. Abacaxi. In: RAIJ, B. van et al. (Eds.) Recomendações de adubação e calagem para o Estado de São Paulo. 2.ed. Campinas: IAC, 1996. p.128. (Boletim Técnico, 100)

TEISSON, C.; LACOEUILHE, J.K., COMBRES, J.C. Le brunisement interne de l'ananas. V. Recherches des moyens de lutte. Fruits, Paris, v.34, p.399-415, 1979.

TEIXEIRA, L.A.J., SPIRONELLO, A., FURLANI, P.R., SIGRIST, J.M.M. Parcelamento da adubação NPK em abacaxizeiro. Revista Brasileira de Fruticultura, Jaboticabal, v. 24, p.219-224, 2002.

VELOSO, C.A.C., OEIRAS, A.H.L., CARVALHO, E.J.M., SOUZA, F.R.S. Resposta do abacaxizeiro à adição de nitrogênio, potássio e calcário em latossolo amarelo do nordeste paraense. Revista Brasileira de Fruticultura, Jaboticabal, v. 23, p.396-402, 2001. 